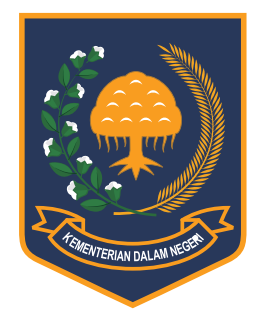

Jurnal Bina Praja 10 (1) (2018): 47-55

Jurnal Bina Praja

e-ISSN: 2503-3360 | p-ISSN: 2085-4323

Accreditation Number

735/AU2/P2MI-LIPI/04/2016

http://jurnal.kemendagri.go.id/index.php/jbp/index

\title{
LICENSING INNOVATIONS IN IMPROVING REGIONAL INVESTMENT IN BOYOLALI REGENCY
}

\author{
Adi Suhendra* \\ Research and Development Agency, \\ Ministry of Home Affairs, Republic of Indonesia \\ Jalan Kramat Raya No. 132, Senen, Central Jakarta
}

Received: 6 March 2018; Accepted: 4 April 2018; Published online: 12 May 2018

DOI: $10.21787 / j b p .10 .2018 .47-55$

\begin{abstract}
Ease of investing supports the competitiveness of the region. Currently the licensing process in Boyolali Distric has a number of problems, among others, not all head of regions/head of Departments agree to delegate their authority to the head of Department of the One Stop Integrated Service (DPM-PTSP), insufficient human resources, and conflict between the licensing agency in the region with the technical unit (formed by the decision of the District Head that consists of elements of the related Regional Work Unit in charge of carrying out the field examination, technical discussion and provide recommendations/considerations regarding a license). The purpose of this study is to describe the efforts of the regional government in solving problems in the delegation of authority to the DPM-PTSP, overcoming the limitation of human resources and the conflict between the technical unit of the licensing services, transparency, accountability and certainty for the applicant. This study is using the qualitative case study approach. Data collection methods were conducted through in-depth interviews, secondary data and field observations. For the validity of the data, the researchers perform data triangulation. The sources of this study are the Head of Boyolali District, the Head of DPMPTSP and its officers. For data processing, the researchers perform open coding, axial coding and selective coding. The findings of this research are that some of the problem are solved by issuing the Boyolali Head of District Regulation Number 10 of 2013 Regarding Implementation Guideline of the Head of District Regulation Number 4 of 2012 (on the Integrated Licensing and Non-Licensing of Boyolali District) to delegate the District Head authority and synchronize the OPD. To overcome the limitations of their human resources, an online licensing application was created to provide an effective and efficient licensing process in Boyolali District.
\end{abstract}

Keywords: The Licensing Service, Investment, Regional Governments, Regional Innovation

\section{INTRODUCTION}

The growth of investment in Indonesia is still not good. The World Bank raises Indonesia's Ease of Doing Business (EoD) rating from 106 to 91 . The rating was conducted to 190 countries in the Asia Pacific region. The World Bank (2017, p. 15) shows that with the increase of the rank to 91 on the Ease of Doing Business, Indonesia had surpassed the Philippines that are in number 99. However, Singapore, Malaysia, Thailand, Vietnam and Brunei Darussalam are still much better than Indonesia's EoD. In the ASEAN, Singapore is still in the top spot, number 2, or one spot higher from the previous ranking in the top 3. Brunei Darussalam also climbed to number 72 from the previous spot of 97 .
Other than that, The Global Competitiveness Report annual report of the World Economic Forum (WEF) shows Indonesia's competitiveness slides down two points in 2012 to 46 from to number 44 in 2011. In 2013 it drops farther by four points, to 50. Then in 2014 Indonesia rises to 38 and again rises in 2015 to 34 in the year 2015, however in 2016 it slides down again to 37 from 144 countries in the world (World Economic Forum, 2016, p. 15). As the results indicated for the past 5 (five) years Indonesia's competitiveness remains stagnant. To strengthen the competitiveness of the regions, the Regional Governments need to make changes in the licensing management processes.

\footnotetext{
* Corresponding Author

Phone : +6282244468840

Email : adisuhendra.pm@gmail.com
} 
Indonesia started to reform the government administration with the enactment of law No. 23 of 2014 regarding the Regional Government (Pemda). The law provides a basic framework for the central government in regulating regional government in Indonesia. Further, the Government Regulation No. 18 of 2016 regarding the Organization of the Regional structures, the regional institutions were directed to be optimized. In this regulation the Government's bureaucratic simplification efforts directed to be more proportionately, flat, short hierarchy and decentralized authority. The main purpose of the rearrangement is to empower regional government to run the main duty and functions in economical, effective, efficient, and accountable ways.

In tune with the above purpose, decentralized or the regional autonomy have provided opportunities for regional governments to strengthen their public service in favor of the public interest. With the regional autonomy, the implementation of the general tasks of governance and development can move faster and with a good quality. The success of the regional autonomy is very dependent on the financial capacity of the region, the human resources capability, and the ability of the region to develop their existing potential. As such, regions, with all of their ability, is trying hard to maximize its economic potential. One of the economic potentials that is a priority for the regional income is derived from licensing services (Muallidin, 2011).

In Boyolali district, the regional government realized that the licensing issues in the region was complicated. In the DPM-PTSP Boyolali District's annual report, the District identifies some issues such as, lack of coordination between OPD with the vertical institutions. This certainly could hinder the issuance of license and permits in the area, the second issue, the cross ministries regulations which were passed down to the District's OPD which overlaps and not in accordance with the existing regional regulation, The spatial planning regulation which can not keep up with the use of land for investment activities, some of the license and permits stipulated in the Regional regulation (Perda) Number 4 of 2012 regarding the Integrated Licensing and Non-Licensing Services in Boyolali District are not effectively enforced and need to be reviewed again.

The third problem is the limitations human resources (HR) quantity and capability to manage the PTSP specially to accelerate the process and handling the online licensing service. According to the annual report, the number of DPMPTSP Boyolali District's employees was only 24 persons. While there are a thousand applicants applying for licenses in one year, with a total investment value of more than 1 trilion (Boyolali District, 2015, p. 44).
Those issues are also similar the findings of the Capital Investment Coordinating Agency (BKPM) regarding licensing problems. Only 41 percent of regional governments delegated their authority to the head of PTSP. The reason, not all head of regions/head of departments would like to delegate their authority regarding some departmentspecific permits/licenses, such as those related to health and environment which need necessary recommendations, to the head of PTSP, human resources limitations and conflict between regional licensing agencies and with the technical agency (Tarigan, 2015).

There are previous studies regarding the licensing service. Such as Osman, Bachok, Bakri, \& Harun (2014) study which evaluates the effectiveness and efficiency of public services carried out by regional authorities in the State of Perak, Malaysia. In this study, it is important to gauge the public perception toward the government as a whole. As many as 250 respondents in 10 local government was selected in this study. This study was conducted to assess the level of performance of the local authorities in Perak.

Similar with Osman, a study by Karim (2015) studied citizen satisfaction of the E-government services dealing with changes to the public service in Bangladesh India, this research described the problem public administration was using traditional ways. The study stated that the public was not satisfied with the old way that the Government provided the service, using paper, long queues, delays in service. To provide better services to citizens, the Bangladesh Government has taken initiatives to provide online services. The Government established a national web portal, combined and makes all official government websites interactive. The common people can file their application online to get the needed public services.

Unlike the study above, Bryan (2013) discussed investment in Washington D.C. This study described Fiscall Cliff, that is a political turmoil which leads to the disarray of policy. This study found that contemporary monetary policy affects the political dynamics. Although the policy is uncertain and its impact on the expansion of business applies to the US, the implications could be applied in other countries. The results of this study help in improving the management practices.

From Indonesia, a study by Pratama (2013) reviewed licensing process. A descriptive study of a value-added public service innovation in Kediri, this study looked at the ease of licensing for the micro, small, and medium business (UMKM) in Kediri. The issue being studied was a formerly difficult, convoluted licensing process which was made easier. Some of the changes of the licensing service were, first, ease of access to information 
for the UMKM applicants to process their business license, second, ease of access for services specific for the UMKM, and third is the ease of the terms and conditions applicable for the UMKM.

Another study by Kartikasari (2017), aimed to analyze the effect of export, import and investment to the economic growth of Riau Islands Indonesia. The data was obtained from the quarterly regional economic report of Riau Islands Province in the period of 2009-2016 or 8 years. The free export and import figures were based on the value reported by importers/exporters to Indonesia's customs. While investment was measured by the value of syndicated loans reported by all banks to Bank Indonesia, and the economic growth by the gross regional domestic product provided by the Central Bureau of Statistics. Panel data regression analysis is performed to analyze the effect of independent variable toward the dependent variable. Simultaneously, these three variables have a statistically significant influence towards the economic growth of Riau Islands Province.

This study would discuss a different issue from previous studies. This study would discuss the innovation produced by the Regional Government of Boyolali to solve problems surrounding the investment. Policy and technology innovations are changing the paradigm, with a Pro investment mission. In the theory of innovation by Rogers (1995) regarding the significance in the decisionmaking process of innovation, the theory among other things describes variables that influence on the level of adoption of an innovation as well as the stages of the decision-making process of innovation. Variables that influence on the innovation diffusion stages include (1) perceived attributes of innovation), (2) types of innovation decisions, (3) communication channels, (4) nature of the social system, and (5) the role of change agents.

Some regional governments made a variety of improvements and breakthrough innovations in the reform of licensing services. The licensing service reform efforts carried out by the regional government are not only striving to increase the Regional Revenue (PAD), but also as a form of responsibility of the government to protect its people against the negative externalities of the socioeconomic activities. Because with a good licensing service, a conducive economic environment would be created. In the context of the licensing service, the study will review about how the head of the region delegates the licensing authority to the head of the licensing department, harmonize the technical department and the licensing department as well as solving the human resource problem.

\section{METHOD}

This research was conducted in Boyolali Regency by using the qualitative approach. The qualitative approach was selected because it enables the researchers to describe the subject sharply, gets the depth of information, and a wealth of interpretations (Somantri, 2005). For the data collection, the researchers conducted interviews, focus group discussion, field observations and data source triangulation. According to Denzin (2012) triangulation of data source is used to verify the validity of a specific information through a variety of methods and data sources. For example, asides from conducted interviews and observation, and reviewed written document and archive, researchers also conducted interviews with some of the sources from the District Head and DPM-PTSP officials in Boyolali and in Jakarta. Data retrieval was performed in July to December 2017.

The interview was carried out on a number of sources, which were the Head of Boyolali District, the Head of DPMPTSP office and the Head of suboffice of Investment. Data processing was using data reduction technique with open coding, whereby the result of the interviews was written in the form of a transcript. This process was conducted by detailing, testing, comparing, the conceptualization of the sources in Boyolali District. The axial coding was conducted by categorizing the issues that are found around the licensing services in Boyolali District. and the selective coding was conducted by connecting several other categories selectively by determining the issues and discussion of licensing data found in Boyolali District.

The location of this study is the Boyolali District Government. This district was chosen because it was selected as the recipient of the 2013 Innovative Regional Government Award by the Ministry of Home Office, the 2014 Investment Award for the Best One-Stop Integrated Service (PTSP) for Investment- Best District/City by the Capital Investment Coordination Board (BKPM), the TOP 99 National Public Service Innovation Competition at the National level from the Ministry of Administrative Reform (BKN) and the 2016 Best One-Stop Integrated Service (PTSP) for InvestmentBest District/City from BPKM.

\section{RESULTS AND DISCUSSION}

\section{A. The Delegation of Authority for Licensing}

Referring to Law 23 of 2014 on Regional Government, licensing process in the district is performed by the One-stop Integrated Service in the field of investment which is the authority of 
Table 1.

Governance Distribution in the Field of Investing

\begin{tabular}{|c|c|c|c|}
\hline Sub Issues & Central government; & Province & District/City \\
\hline $\begin{array}{l}\text { Capital Investment } \\
\text { Service }\end{array}$ & $\begin{array}{l}\text { 1. Investment in several } \\
\text { provinces. } \\
\text { 2. Investment related to } \\
\text { non-renewable natural } \\
\text { resources with a high } \\
\text { risk of environmental } \\
\text { damage. } \\
\text { 3. Investment in a high } \\
\text { priority industry. }\end{array}$ & $\begin{array}{l}\text { The Integrated One- } \\
\text { Stop Licensing and Non } \\
\text { Licensing Service for } \\
\text { 1. Investment in several } \\
\text { Districts/Cities; } \\
\text { 2. Investment which } \\
\text { based on the laws and } \\
\text { regulations is under } \\
\text { the authority of the } \\
\text { Province. }\end{array}$ & $\begin{array}{l}\text { The Integrated One- } \\
\text { Stop Licensing and } \\
\text { Non-licensing service } \\
\text { on investment on those } \\
\text { under the authority of the } \\
\text { District/City. }\end{array}$ \\
\hline
\end{tabular}

Source: Law of the Republic of Indonesia Number 23 of 2009 on Regional Government

district/city. According to Law No. 25 of 2007 on investment, Licensing Service is defined as all forms of approval to conduct capital investment issued by the government and regional government that has authority in accordance with the provisions of the prevailing laws and regulations, which includes: Capital Investment Registration License; Capital Investment Principle License, Expansion Principle Licence, Amendment Principle Licenses/Business License, Expansion of Business License, Merger Business License andAmendment Business License.

The District's licensing and non-licensing services is only for those under the authority of the region, which refers to the Concurrent Governance. The Concurrent Governance is those governances which are distributed between Central Government, the Province, and the Regional District/City. The Concurrent governance divided into the mandatory government affairs and optional government affairs. The Mandatory Government Affairs are those that must be performed by all regions. While the Optional Government Affairs are those that must be conducted by specific region in accordance with the potential of the area. The licensing authority distribution is described in Table 1.

In accordance with Table 1, the District/ City authority in providing the licensing and nonlicensing service is only for those investments under the authority of the District/City. There are two types of regional authority in law 23 of 2014 on the concurrent governance, which are the mandatory affairs and the optional affairs. The mandatory matters are divided into basic services and nonbasic services.

In 2011, the Ministry of Home Affairs also issued letter number 570/3172/SJ on August 19, 2011, on The Implementation of Licensing and NonLicensing Authority in the field of Domestic Capital investment Through Regional PTSP. The regulation was issued as the follow up of the issuance of the Head of BKPM Regulation number 14 of 2011 on the
Minimum Service Standard on Capital Investment in the provinces and District/City. In the regulations, BKPM stipulates compulsory minimum service standards on Licensing and Investment services to be conducted by the Regions.

The PTSP for capital investment is also regulated by Law No. 25 of 2007 on Capital Investment. Based on the law, PTSP objective is to help the investor to access the investment services, fiscal facilities, and information on investing. The activities of the PTSP is defined as a licensing and non-licensing activities, it obtained its delegated authority from the authorized institution, and its processes, from the application stage until the issuance of the documents in one place.

In Boyolali District, the licensing service is conducted by the Organization of the Regional Office (OPD) Capital Investment Board and OneStop Integrated Service (BPMPSTP). This structure refers to Boyolali District regulation number 16 of 2011 on the Organization and governance of the Boyolali District. However, since the issuance of Government Regulation Number 18 of 2017 on Regional Government Organizations, the licensing service which was previously a licensing agency is now as an OPD Office.

The DPMPSTP Boyolali District, which basic task is helping District Head in governing the district in investment and licensing, has a strategic role in developing Boyolali. The efforts undertaken by the community in Boyolali will increase the economic activities of the community indirectly. This, in turn, would increase the community's welfare. The DPMPSTP also impacts on the District OwnSource Revenue (PAD), since this office is one of the offices that have income generating role for Boyolali District Budget.

The PTSP for capital investment is also regulated by Law No. 25 of 2007 on Capital Investment. Based on the law, PTSP objective is to help the investor to access the investment services, 
fiscal facilities, and information on investing. The activities of the PTSP is defined as a licensing and non-licensing activities, obtain its delegated authority from the authorized institution, and which processes, from the application stage until the issuance of the documents in one place.

Boyolali District Government has also published a number of regulations in order to improve and organize investment licenses. Among them are Boyolali Regulations number 3 of 2014 on Capital Investment. The purpose of this regulation is to increase the economic growth of the region, create jobs, improve the sustainable and environmentally friendly economic development, improve the competitiveness of the business world in the region, increase the capacity and capability of the technology in the region and encourage the development of people's economy. Another regulation is Boyolali District Head regulation number 9 of 2016 on the granting of disturbance permit to the SME businesses for free. The policy is expected to create a competitive climate for investment in the region.

To delegate its authority and harmonized the OPDs, the Boyolali Government issued regulation number 4 of 2012 on the Integrated Licensing and Non-Licensing Service of Boyolali District. This regulation is intended to delegate the District Head's and other Head of Offices' authority to the Head of PMPTSP Services. Article 1 point 6 of this regulation stated that the One Stop Integrated Service, hereinafter is referred to as PPTSP, is licensing and non-licensing activities which obtain its delegated authority from the authorized institution, which processes, from the application stage until the issuance of the documents in one place.

\section{B. Unravelling the Disharmony}

So far, the problems arising in the investment processing in the region are the lack of coordination between the OPD and vertical agencies. This affects the completion of licenses. It may inhibit the attainment of Boyolali City as a Pro - Investment City. All OPD relating to licensing and investment should integrate the interests and needs of the applicants in their programs and activities.

Findings from the field illustrate how the disharmony in licensing occurs in the central and regional levels. One of the cases is the regulation of spatial plan that is not in sync with the pace of land use for investment. In the interview, the head of the DPMPTSP provides an example about entrepreneurs who need a thousand square meters land. However, in certain cases, the entrepreneurs are not allowed to buy it, and eventually, lease the land which sometimes is owned by the village. The term of the lease is Build, Operate, Transfers, which benefits the village government. The problem is that there is a discrepancy if there are entrepreneurs who will make the investment but the land being used is the owner of the village. In several events, the IMB of the land is pledged by the tenant.

It seems that the understanding of the actual licensing process is also not far from the involvement of society in the discovery of a collective consciousness. By understanding the nature of human existence and the humanitarian dimension, Weber States that the individual or individuals as a person, a human being will not be able to live and evolve based only on his/her own ability. They need social institutions, society, and country and vice versa (Giddens, 1971). The DPMPTSP needs a common perception with the community regarding legal boundaries in licensing. Because that problem, the Head of District instruct the Head of DPMPTSP to put several licenses that were handled by the technical service, under the DPMPTSP.

As an effort to solve the disharmony, the Boyolali Government issued a policy to merge the licensing under one office. There are 46 Licenses provided under the DPMPTSP of Boyolali district as stated in the regulation number 4 of 2012 and are classified in two types: licensing which is subject to regional charges and licensing that is not subject to regional charges. Out of 46 licenses, only two of those are subject to regional charges, which are Building Permit (IMB) and disturbance permit (HO). The rest are free of charge.

The steps taken by the Boyolali District harmonize the OPD and the central government, support the ease of investment, ease the management or business licensing, reduce the bureaucracy in the licensing process and even eliminate investment licensing costs except for Building Permit (IMB) and Disturbance Permit (HO). In addition, to support a conducive investment climate, infrastructure development is carried out in the form of road construction, lighting, and clean water.

The Boyolali District Head does have the political ability. According to Franz Magnis Suseno in Utami (2014), the political dimension of human

Table 2 .

Number of Investor and Domestic Investment Value in Boyolali District

\begin{tabular}{crc} 
Year & $\begin{array}{r}\text { Investor } \\
\text { per Year }\end{array}$ & \multicolumn{1}{c}{ Total Investment } \\
2014 & 804 & $3,655,069,805,358$ \\
\hline 2015 & 6,651 & $4,855,000,000,000$ \\
\hline 2016 & 6,922 & $5,399,000,000,000$ \\
\hline
\end{tabular}

Source: DPMPTSP Boyolali District 
being is the dimension of society. As such, what characterizes a political approach is that the approach takes place within a socially oriented framework. Thus, the political dimension of a man can be determined as a dimension in which the man sees himself as a member of society that determines the frame of his life and is redefined by his actions. The political dimension it includes legal and institutional circles of the country, the value systems and the ideologies that give legitimacy to him.

The result was remarkable. From 2014 investment value for Domestic Investment (PMDN) has reached Rp3.655.069.805.358 while for Foreign Investment (PMA) investment value reached US\$55,275,500 and Rp696.784.387.600 (DPMPTSP Book of Kab. Boyolali, 2017). More detail information is presented in Table 2.

As shown in Table 2, the amount of investment continues to increase every year. In 2014 the total amount of investment in Boyolali's is $\mathrm{Rp} 3,655,069,805,358$. At the end of 2016, the Investment value in Boyolali has reached Rp7.92 trillion. The figure is sourced from BPMP2T Boyolali. Head of DPMPTSP Boyolali, ELRusdijanti, through Head of Investment, Eko Nugroho, stated that the investment value is the cumulative value for the last ten years either from domestic investment (PMDN) or foreign investment (PMA). Of this investment value, the domestic investment is still dominant, with the investment value of Rp5,399 trillion and 6,922 companies. While PMA reached Rp1,693 trillion from 10 foreign companies.

Head of Investment Division Eko Nugroho stated that most investors were in the textile industry and the rest are in services, trade and other services. Investment in Boyolali grew rapidly because the District Government provided the PTSA. DPMPTSP also provided convenience in licensing services. "Factors that are also important in boosting investment are the construction of adequate road and bridges".

The services and innovation provided by DPMPTSP also have an impact on the increase of investment, such as SMS Gateway application, online licensing, Boyolali investment potential maps, information platforms, and e-documents.

In addition, various licensing facilities are granted to attract investment, of 48 licenses, only a few licenses are levied, such as Building Permit (IMB). The development of transportation infrastructures such as roads and bridges are also very attractive to investors. Because transportation is one of the important aspects of investment.

Strategy in the form of regulatory breakthrough in licensing service conducted by the Integrated Licensing and Service Agency of Boyolali District is to provide licensing service, as many as 46 types
Table 3.

Number of Boyolali District's DPMPTSP Employee

\begin{tabular}{lll}
\multicolumn{1}{c}{ Position } & Echelon & Number \\
Head & II & 1 Person \\
\hline Secretary & III/a & 1 Person \\
\hline Section Head & III/b & 3 Persons \\
\hline Head of Sub-Section & IV/a & 3 Persons \\
\hline Head of Sub-Section & IV/a & 2 Persons \\
\hline Staff & & 24 persons \\
\hline
\end{tabular}

Source: DPMPTSP Boyolali District

of licenses and only 2 (two) license is charged (Building Permit (IMB) and Disturbance Permit (HO)) while others are provided free of charge The result, the innovation of regulatory strategy became a special attraction for investors to invest in Boyolali District both for Domestic and Foreign Investment (PMA).

\section{Handling the HR Crisis}

Despite benefiting from the supporting factors of policy and technological innovation, the Boyolali district still has various challenges which can be regarded as a limiting factor in the ProInvestment move. First, the limited quality and quantity of human resources in PTSP, especially in the framework of acceleration and online licensing service This analysis refers to the workload of the employees. Workload analysis is the process of determining the number of hours being used or required to complete a job within a certain time, or in other words, the workload analysis aims to determine how many personnel and how many tasks or workloads should be assigned to an officer.

Table 3 shows that there are only 24 people employees in DPMPTSP Boyolali District, while there are thousands of applicants applying for licenses in one year, with a total investment value of more than 1 trillion Rupiah. The DPMPTSP main task and function are to provide licensing services. Its employee is required to performs field check as part of the verification stage of the licensing process.

Boyolali District Government realizes that there is a need to adjust the administration process to enable a fast, efficient service to fulfill the public expectation. As the result, the government provides innovation services in DPMPTSP which in turn manage to increase Boyolali's investment.

In addition to innovation in its policy, Boyolali District also innovates in the field of technology to 
overcome the lack of human resources. DPMPTSP creates some applications to ease and speed up the licensing process. Such as SMS Gateway, Online Licensing, Boyolali District Potential Investment Map, Information center and e-document. The technology is intended to enhance the licensing and non-licensing service, ease of access and increase the certainty of the application process.

Boyoyali District's Innovation providing acceleration and easiness of licensing application services. For instance, the online licensing application stages started with the applicant registering the types of permits at http://dpmptsp. boyolali.go.id/web. The applicant is directed to the login menu and fills out the online form. Then the applicant uploaded the necessary documents and the officers would verify the applications documents, process the applications, discuss with the Head of DPMPTSP and finally sign the decision letter to approve or to deny the application. The applicant then receives the license in the PDF form, or they can pick up the license directly from the DPMPTSP.

Other than the online license application, the government also lessen the workload of the DPMPTSP employee and increase the quality of licensing process by: First, using the Licensing Service Information System Application, to ease the licensing process. The objective of the application is to save the time of license processing.

Second, The District also has a parallel process where the same documents may be used for several license applications. This is meant to shorten the licensing process. Third, communicates the licensing service to the public, via various means directly to the sub-districts and via radio programs: Merapi FM, Karysma FM and CJDW FM, and via DPMTP website. Fourth, a mobile unit for license registration is going to be launch with the cooperation of BPJS Ketenagakerjaan of Klaten Branch. And fifth, a sub-District Integrated Administrative Service Application (PATENT) is going to be implemented for some specific types of licensing that need the sub-district process, to enable the applicant to process the license from the Sub-District instead of going to the District's DPMPTSP.

It seems that the regional government innovation is a key change. Innovation is an idea, practice or object that is considered recently by the individual. Innovation may be in the form of new product or services, new production technology, new structure and administration system, or new plan for the organization.

Innovation in the public sector is the way or even the breakthrough needed to address the organization blockage. The public sector's characteristic of being rigid and tend to be in a status quo need to be solved with innovation. Innovation, which is more known in the dynamic sector such as the business sector, slowly is being introduced in the public sector and gaining attraction.

It is linked to the external dynamics and change of demands outside the Organization, better literacy levels and awareness of the public regarding their rights. The public sector can accommodate and respond quickly to any changes that occur. The policy of issuing regional innovation is much studied in the western world. Ogburn and Nimkoff in Useem (1956) studied the social invention, Teofilovic (2002) discussing innovation in government, and De Vries, Bekkers \& Tummers (2016) which examines innovation in the public sector.

Rogers (1995) described the Boyolali District phenomenon as Innovation Diffusion. Innovation Diffusion basically explains the process by which an innovation is communicated through certain channels over time to a group of members of the social system. Rogers stated that diffusion as "the process by which an innovation is communicated through certain channels over time among the members of a social system." A diffusion is a specific form of communication regarding the dissemination of messages of new ideas.

\section{Conclusion}

The focus of this study is the pro-investment policy issued by Boyolali district government and implemented by DPM-PTSP 2016 which has been running effectively. This is shown with the achievement of the yearly investment increase.

Although in there were some problems in the implementation of the policy, it did not affect the effectivity of the policy, the DPMPTSP, the investor and the public were able to solve the problem using technology innovation to address the lack of human resources, the use of the parallel licensing process, the continues communication of the licensing process and extension of the integrated licensing process to the sub-district level.

Based on the study on Boyolali District, there are at least three main elements enabling the District to innovate its licensing services. First, the licensing innovation is considered as new ideas, new actions or new thing by the public. In this case, the novelty of innovation is measured subjectively according to the individual views. If an idea was considered recently by someone then it is an innovation for that person. The concept of the ' newness 'in the innovative ideas does not have to be new for everybody.

Second, the pro-investment regional regulation seen as a communication channel. As a tool to convey innovation messages from the source to the recipients (the public). To choose the communication channel, the source at least need to consider: (a) the purpose and (b) the recipients characteristic. If the communication purpose is to 
introduce new innovation to the general public, then the most effective, fast and efficient channel is the mass media. If the communication purpose is to change the attitude or behavior of the individual recipient, then the effective communication means is the interpersonal channel.

Third, the Time, the process started with the evaluation of the licensing process, the decision to innovate and the issuance of the decision which all takes time. At least the program already running for more than five years, since Mr. Seno Samodro was elected as the Head of District and the fourth, the social system, the various units bounds in teamwork to solve various problems to achieve a common goal. We see the collective consciousness of the district government, the application developer, and the public, to have a good public service by putting forward the benefit for the public above all things.

We encourage the Central and Regional Governments to align the organization of regional apparatus as well as the vertical institution. This certainly would have an impact, particularly for the licensing recommendations processes, so that it is no longer a constraint on the licensing process.

\section{ACKNOWLEDGEMENT}

The author would like to thank the Head of Research and Development Agency, Head of Research and Development Center of Regional Innovation of Research and Development Agency of the Ministry of Home Affairs, the Governor of Central Java province, and DPMPTSP Boyolali District as well as Sociologist Dr. Ivanovich Agusta (IPB) for the many input for this study.

\section{REFERENCES}

Boyolali District. (2015). Boyoloali Pro Investasi. Laporan Perkembangan Investasi di Kabupaten Boyolali Tahun 2010-2014. Boyolali: DPMPTSP of Boyolali District.

Bryan, J. L. (2013). The Impact of Government Policy on Economic Growth. Management Faculty Publications. Retrieved from http:// vc.bridgew.edu/management_fac/23

De Vries, H., Bekkers, V., \& Tummers, L. (2016). Innovation in the Public Sector: A Systematic Review and Future Research Agenda. Public Administration, 94(1), 146-166. http://doi. org/10.1111/padm.12209

Denzin, N. K. (2012). Triangulation 2.0. Journal of Mixed Methods Research, 6(2), 80-88. http:// doi.org/10.1177/1558689812437186

Giddens, A. (1971). Capitalism and Modern Social Theory. Cambridge: Cambridge University Press. http://doi.org/10.1017/ CB09780511803109

Karim, M. R. (2015). E-Government in Service
Delivery and Citizen's Satisfaction: ACase Study on Public Sectors in Bangladesh. International Journal of Managing Public Sector Information and Communication Technologies (IJMPICT), 6(2), 49-60. Retrieved from http://airccse. org/journal/mpict/papers/6215ijmpict05. pdf

Kartikasari, D. (2017). The Effect of Export, Import and Investment to Economic Growth of Riau Islands Indonesia. International Journal of Economics and Financial Issues, 7(4), 663-667. Retrieved from http://www.econjournals. com/index.php/ijefi/article/view/5217

Muallidin, I. (2011). Kebijakan Reorganisasi Perizinan Untuk Meningkatkan Kualitas Pelayanan Publik Di Kota Yogyakarta. Jurnal Studi Pemerintahan, 2(2), 398-423. http:// doi.org/10.18196/jgp.2011.0020

Osman, M. M., Bachok, S., Bakri, N. I. M., \& Harun, N. Z. (2014). Government Delivery System: Effectiveness of Local Authorities in Perak, Malaysia. Procedia - Social and Behavioral Sciences, 153, 452-462. http://doi. org/10.1016/j.sbspro.2014.10.079

Pemerintah Republik Indonesia. (2014). UndangUndang Republik Indonesia Nomor 23 Tahun 2014 tentang Pemerintahan Daerah. Jakarta: Sekretariat Negara.

Pratama, M. R. (2013). Inovasi Pelayanan Publik (Studi Deskriptif tentang Nilai Tambah (Value Added) Inovasi Pelayanan Perizinan bagi Masyarakat di Kota Kediri). Kebijakan Dan Manajemen Publik, 1(2), 218-225. Retrieved from http://journal.unair.ac.id/KMP@ inovasi-pelayanan-publik-(studi-deskriptiftentang-nilai-tambah-(value-added)-inovasipelayanan-perizinan-bagi-masyarakatdi-kota-kediri)-article-5553-media-138category-8.html

Rogers, E. M. (1995). Diffusion of Innovations (4th ed.). Free Press.

Somantri, G. R. (2005). Memahami Metode Kualitatif. Makara Seri Sosial Humaniora, 9(2), 57-65. http://doi.org/10.7454/mssh.v9i2.122

Tarigan, A. (2015, January 8). Dilema Birokrasi Satu Pintu. Retrieved from https://nasional. kompas.com/read/2015/01/08/19033681/ Dilema.Birokrasi.Satu.Pintu

Teofilovic, N. (2002). The Reality of Innovation in Government. The Innovation Journal: The Public Sector Innovation Journal, 7(3), 1-19. Retrieved from https://www.innovation. cc/scholarly-style/7_3_4_teofilovic_realitygovernment.pdf

Useem, J. (1956). Technology and the Changing Family. W. F. Ogburn, M. F. Nimkoff. The American Journal of Sociology, 62(1), 131-132. http://doi.org/10.1086/221948 
Utami, R. (2014). Taman Cerdas sebagai Simbolisasi Kota Layak Anak di Surakarta (Studi Kasus di Kelurahan Kadipiro Kecamatan Banjarsari Kota Surakarta). Sosialitas (Jurnal Ilmiah Pendidikan Sosiologi Antropologi), 4(1). Retrieved from http://jurnal.fkip.uns.ac.id/ index.php/sosant/article/view/4032
World Bank. (2017). Doing Business 2017: Equal Opportunity for All. Washington, D.C.: World Bank. http://doi.org/10.1596/978-1-46480948-4

World Economic Forum. (2016). The Global Competitiveness Report 2016-2017. (K. Schwab, Ed.). Geneva: World Economic Forum. 